\title{
Energy Landscapes and Environmentality: Boundaries between Discourses and Practices in Energy Governance
}

\author{
Arnoldo Lima and Fabiano Toni
}

\begin{abstract}
Energy resources are critical to the development of mankind. Different forms of energy governance can promote innovative environmental subjectivities, but eventually become the stage of constructed rationalities that legitimate the predatory use of natural resources. Thus, the concept of environmentality is used as a theoretical frame to analyze how discourses are used to legitimate the pace, use, and forms of energy production. Primary data were collected in two energy landscapes: Gaucho Biodiesel Pole in Brazil, and Eagle Ford Shale in the United States. Despite distinctive materiality and different governance structures the results pointed to a common timely environmentalism, based on an empty rhetoric.
\end{abstract}

Index Terms-Energy landscapes, governance, environmentality, biodiesel, shale.

\section{INTRODUCTION}

Energy is essential to the development of mankind. Its forms of regulation and management are decisive to define the quality of exploitation and production. Beyond the energy resource materiality, processes, structures and speeches linked to the governance of energy resources carry the potential to promote socio-environmental impacts. Thru this perspective, we focus on the speeches, discourses and environmental subjectivities that emerge from power relationships amongst energy stakeholders.

The results presented here were obtained as a part of a comparative research conducted in two different energy landscapes: the Gaucho Biodiesel Pole (GBP) in Brazil, and the Eagle Ford Shale (EFS) in the United States.

The research concludes that although biodiesel and shales have different materialities and distinctive political-institutional arrangements, the exploitation and marketing of both is based on a "timely socio-environmentalism," This means the construction of appropriate subjectivities designed to legitimated energy production as a propeller to sustainable development. Thru this discussion, this work aims to debate the boundaries between good and spurious practices on energy resource governance.

The paper is structured as follows: in the first section, after this introduction, we present the mains concepts and the theoretical framework deployed in the research. Next, we present the two study areas where we collected our data - the

Manuscript received June 20, 2017; revised August 24, 2017. This work was supported in part by the U.S. National Science Foundation (NSF), Brazil Coordination for the Improvement of Higher Level Personnel (Capes) and Federal District Research Foundation (FAPDF).

The authors are with Universidade de Brasília, Centro de Desenvolvimento Sustentável, Brasília, Brazil (e-mail: arnoldosan@gmail.com, fabtoni@gmail.com).
Gaucho Biodiesel Pole, in Rio Grande do Sul State, Brazil; and the Eagle Ford Shale, in Texas, United States. In the following section, we present the methods, results and the discussion.

\section{ENERGY LANDSCAPES, GOVERNANCE AND ENVIRONMENTALITY}

\section{A. Energy Landscape and Governance}

The study of energy landscapes emerges as a field of research linked to Ivan Ilich's [1] "social construction of energy", in which energy production assumes the role of agent and product of socio-spatial organization.

From this perspective, Nadai \& Horst [2] pointed that analyzing energy thru the landscapes lens is critical not only to understand resources materialities over the production areas, but especially to reveal new multidimensional, correlational and political aspects involved in energy chains.

Among those dimensions, Smith et al. [3] and Geels \& Schott [4] point out to the emergence of innovative governance structures, which includes increased society participation. Innovative governance often implies the emergence of non-state market-driven arrangements, as highlighted by Cashore [5] and Swyngendouw [6]. Those arrangements however may evolve into authoritarian forms with low legitimacy and low society engagement, in an opposite way of good governance systems [7].

In this sense, energy landscapes around conventional, renewable (i.e. wind, solar, biomass) or even non-conventional resources (i.e. bituminous sands, shales, geothermic) are set up as stages for the development of new forms of collective action and participatory management, but also arenas for the development asymmetrical power relationships and cooptation.

\section{B. Environmentality}

The concept of environmentality rises from state-society interactions concerning environmental politics, processes and technologies that create specific rationalities, discourses and new subjects. To Luke [8], [9] environmentality emerges beyond the scientific sphere, connected to corporations and official state agencies where new conceptions and codes are employed to emphasize environmental commitment to natural resource management. Discourses and concepts of nature, environment and sustainability are embraced as a means to legitimize neoliberal forms of management under the guise of pluralist forms of governance.

Agrawal [10] presents environmentality as the emergence of environmental subjectivities connected to new participatory political experience and society engagement in 
innovative regulatory practices. To the author, the introduction of forest resources governance to local communities of Kumaon, India, was able to produce the modification of the logics and postures in the use and exploitation of natural resources.

Observing environmentality patterns during the decentralization of fishery governance in New Zealand, Haggerty [11] reported the emergence of "accidental environmentalists" ( $p, 231)$. Those are stakeholders whose behavior was paradoxical: although they would deny being "greenies" they unwittingly assumed environmental practices and postures due to the emergence of an innovative political layout.

Shoreman \& Haenn [12], in turn, categorize as "reluctant environmentalists" (p.96) the ultraconservative farmers settled at the Mississippi Delta, which also had controversial views of environment protection, but adopted new procedures and speeches to avoid federal regulations.

In one of the first studies aimed at analyzing environmentality in energy landscapes Jepson et al. [13] identified a "reflexive environmental skepticism" in Sweetwater, Texas, the epicenter of US wind energy. Once again, stakeholders did not overturn their subjectivities even as renewable energy became a pillar of the local economy. A view that accepts products, processes and policy innovations without accepting environmental claims and compliance.

\section{Study AREas: Gaucho Biodiesel Pole AND EAGLE FORD SHALE}

The Gaucho Biodiesel Pole (GBP/ Map.01) is the most important biodiesel production zone in Brazil, which is the second biggest market in the world [14]. Three among the six largest Brazilian plants and other six large medium-sized plants are operating in GBP. This energy landscape accounts for $25 \%$ of the domestic biodiesel production, and $21 \%$ of all nominal capacity installed in the country [15].

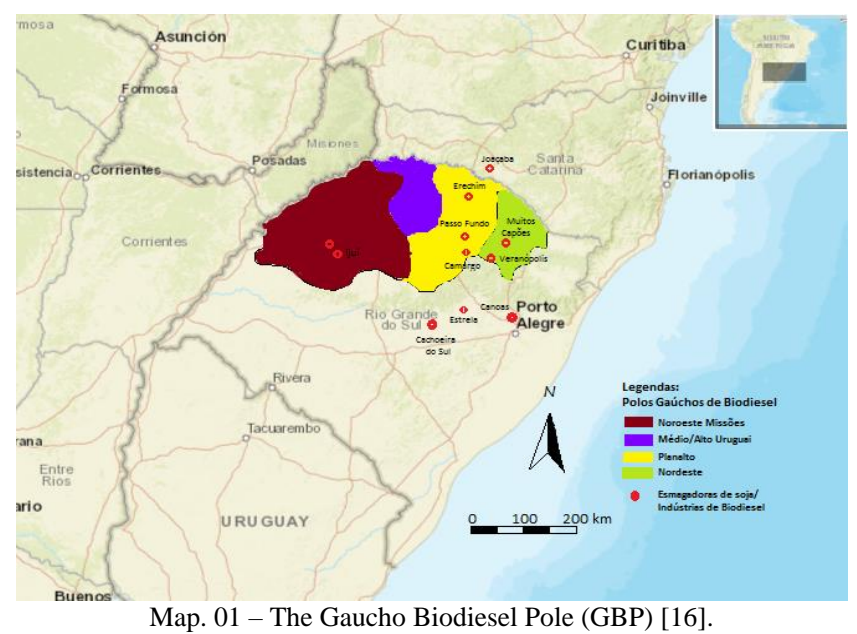

The other study site is Eagle Ford Shale (EFS/ Map. 02) one of the largest and most profitable oil/gas shales in the United States.

Located in southern Texas, this energy landscape has been attracting huge investments since 2013, when energy companies broke ground for infrastructure projects, such as hubs, pipelines, storage terminals and processing plants. The current volume of physical and financial capital - over US\$ 23 billion in 2013 - places EFS as the most exploited shale stock in the world [17].

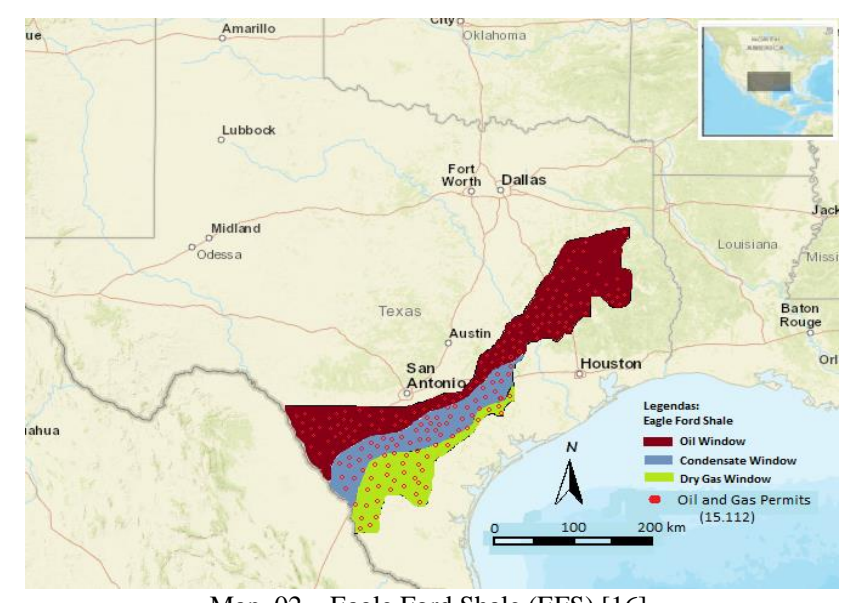

Map. 02 - Eagle Ford Shale (EFS) [16].

\section{Materials AND Methods}

We traveled across eight municipalities and conducted 35 interviews in the Gaucho Pole between May and June, 2014. Interviewees included government officials (at federal, state and municipal levels), farmers, labor union officials, and managers and directors of the main biodiesel plants. We conducted a second round of interviews in eight counties in Texas, between January and February 2015. At the occasion we interviewed 14 stakeholders, which included Circuit judges, NGO leaders, city managers, city councilmen, and local business persons. Representatives from the oils and gas industry declined our interview requests. We also participated in a public hearing held to discuss oil and gas ordinances. The interviews were based on a semi-structured questionnaire. Interviews took from 45 to 90 minutes. Questions sought to understand discursive strategies and to explore perceptions about energy, economics, development, environment and sustainability. Analysis of policy documents, media, iconography and digital materials are also used as data source. All primary and secondary data was fed into the computer quality-data-assessment software Atlas.ti in order to identify patterns to support discourse analysis.

\section{RESUlTS}

\section{A. Economic Growth as Development}

Gaucho Pole and Eagle Ford social actors strongly connected the energy industry to the 'virtuous cycle of production-work-income'. In GBP this pattern is embedded in the economic growth spurred by agriculture and agribusiness activities (Fig. 1). Job creation gained a dimension of the 'morale of hard and uplifting work' [18].

In EFS, for example, job generation is treated as "our most precious commodity" (Fig. 2) and therefore associated with a development mechanism that must be preserved [19]. A strong legitimacy component of that discourse is the claim that there will be "more money in your pocket, bigger revenues, better trade balance, and a gross domestic product growth" [20]. 

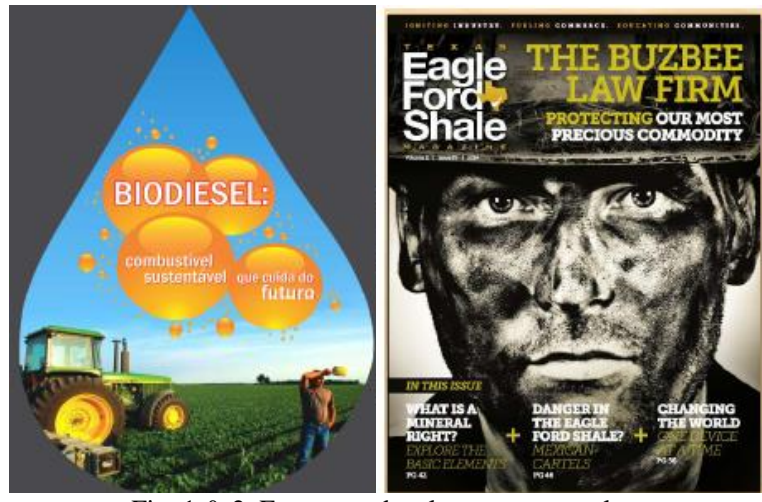

Fig. 1 \& 2. Energy as development proppeler.

\section{B. Science, Technology and Innovation as Paths to Sustainable Development}

The role of science and technology is frequently deployed to emphasize energy chains as propellers of innovative low carbon economies. Although biodiesel is a renewable resource whereas shale gas is non-renewable, the discourses and subjectivities are quite similar.

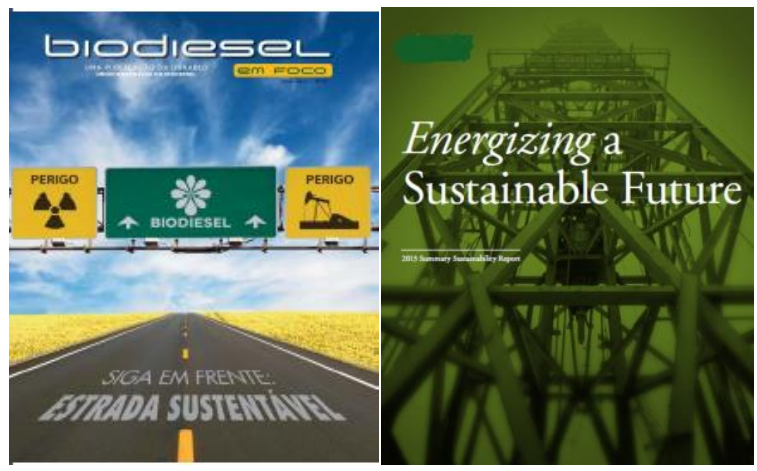

Fig. $3 \&$ 4. Paths to the sustainable future.

An striking example that reflects stakeholders rationality is provided by the producers association magazines that headlines biodiesel as a "Sustainable Road" (Fig. 3) "that take care of the future" [21]. Accordingly, EFS companies claim to be "going green" by "the virtues of fracking" [22] in a way to explore shale gas as a "bridge fuel" [23] able to "Energizing a Sustainable Future" [24] (Fig. 4). Science, technology and innovation are therefore common aspects used to address environmental concerns and to show commitment towards a clean energy transition.

\section{Energy Security and Nationalism}

In Brazil, business executives, government agencies and even public companies such as Petrobras frame biodiesel as a security resource, "the planted energy" (Fig. 5). FrenteBio, for example, a group of Brazilian congressman supported by the lobby of soybean producers, calls biodiesel a "national pride" [25].

We found the same narrative in EFS, thru the American Petroleum Institute, also a national lobby that describes shale exploitation as "America's Energy Revolution" [26] able to assure "U.S. Oil Self Sufficiency" [27] (Fig. 6). On the two situations the discourses highlight the central role of biodiesel and shale as promises of energy independence on foreign products and markets.

\section{Regional Pride and Resource Spectacle}

Rio Grande do Sul and Texas, states that settles the two energy landscapes, also emphasized their proud of being energy producers. In Texas, for example, many see oil and gas exploitation "as a natural part of life," associated with topography, the road network, and even the "Texas culture" that embraces and celebrates "the multiplier effect" (Fig. 7) of new shale boom with gratitude and rejoicing. [28].

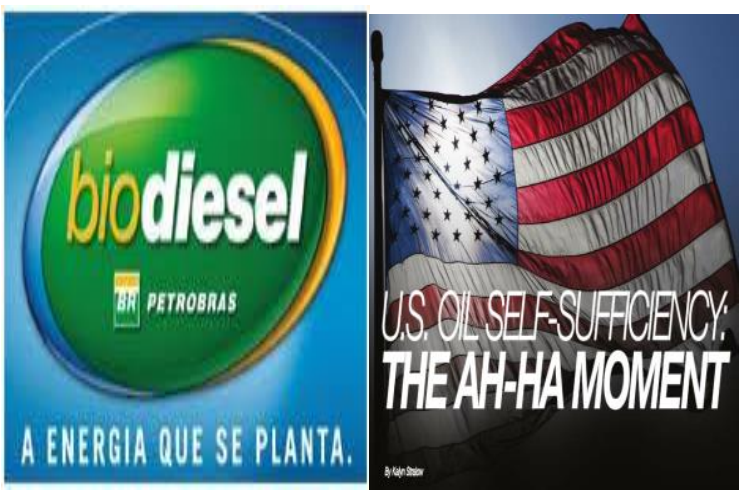

Fig. 5 \& 6. Energy as national pride.

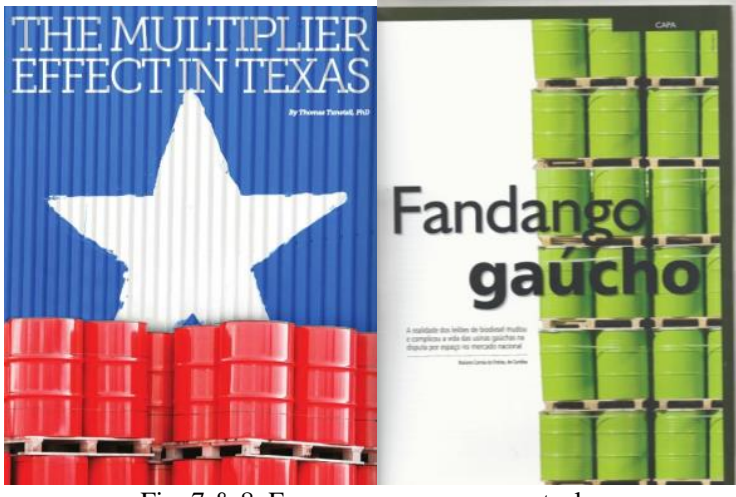

Fig. $7 \&$ 8. Energy as resource spectacle.

A similar association happens amongst bran-oil-biodiesel production in the "Fandango Gaucho" (Fig. 8) due to the historical linkage of soybean production to the development of local economy [29]. Statements like "Brazil needs to explore its green Pre-Salt" (in allusion to the Brazilian deep-water oil reservoir) [30] or do " $Y$ 'll smell it? It's smell like Money!" [31] reflects a disseminated vision of energy resource as a spectacle and the energy production as a source of regional pride.

\section{DISCUSSION}

Discourses, narratives and iconographies are shaped by the construction of undeniably values that interconnect the production of biodiesel and the exploitation of shales as a secure path to the promotion of economic health, social welfare, energy security, nationalism, regional pride and even to a sustainable future.

The paradox however is linked to the characteristic of both energy production chains and to their governance systems. First, biodiesel and shales are rooted in traditional commodities - soy and oil/gas respectively - with well known environmental impacts [32]-[35]. Second, political and institutional arrangements in the two energy landscapes have not been effective to promote good governance systems. 
In the last decade biodiesel grew its market share by replacing fossil fuels. Gaucho Biodiesel Pole witnessed the vertical integration of traditional oil companies that received substantial subsidies from the Brazilian National Bank for Economic and Social Development (BNDES) [36]. Since then, a fierce competition started amongst large companies, due to the international increase in soybean prices and the increased profitability of bran and grain trade. That was a powerful race that boosted the land change use linked to the expansion of soy plantations, in an opposite direction of an environmentally friendly biofuel [37].

During the same period, the exploitation of Eagle Ford was legitimated thru the perspective of replacing coal by shale gas in a way to produce clean energy. Indeed, this is the main rationale for companies and development agents to refer to shale as a "bridge" for a sustainable future.

Nonetheless, the gas oversupply since 2012 caused a sharp drop in prices and lead companies to incinerate the non-profitable resource [38], [39]. This loss was counterbalanced by the increase of shale oil exploitation. As a result, Eagle Ford watched the multiplication of flares on drilling spots, which are linked to risk of oil spills and atmospheric contamination by volatiles organic compounds [40], [41].

It is worth emphasizing that we are discussing here the emergence of environmental subjectivities linked to energy governance over energy landscapes. The two study cases in this matter are illustrative of specific types of discourses constructed by specialized sectors to highlight social and environmental compliances.

Thru this perspective a "timely socio-environmentalism" seems to be a common pattern in Gaucho Biodiesel Pole and Eagle Ford Shale. Timely refers to the appropriate, propitious or favorable discourses from industry stakeholders aimed at ensuring their social and environmental commitments. As pointed by Luke [8], [9] a designed environmentality outlined to legitimize both energy production chains by putting market goals aligned with society and state interests.

This pattern leads to a crucial point: to understand how governance systems can promote spontaneous environmental subjectivities or, conversely, become political and institutional arrangements that shape subjectivities just for legitimating contemporary energy politics.

\section{CONCLUSION}

The Gaucho Biodiesel Pole and the Eagle Ford Shale have very distinctive governance systems - discussed and analyzed by the author elsewhere [16]. Despite the political and institutional differences, in this paper we identified a 'timely socio-environmentalism' wherein policy makers and industrial actors legitimize the regulation and management of their sectors using discourses that undeniably interconnect energy exploitation to socio-economic and sustainable development.

In the two cases, however, the emergence of such environmentality pattern seems to be linked to unfavorable political and institutional arrangements that fail to offer local communities or any other settled civil associations ways to spontaneously developed new empowerments or innovative collective actions aimed at promoting environmental subjectivities.

In other words, without robust governance, i.e. decision-making systems and processes that promote accountability, participation, equality, and representativeness; spontaneous and legitimate environmental subjectivities, as presented by Agrawal [10], will hardly emerge.

Further research is necessary to generalize our conclusions, but the study of energy landscapes thru the analytical lens of environmentality represents an innovative way to debate the boundaries between speeches and practices on political and institutional arrangements linked to energy governance.

\section{ACKNOWLEDGMENT}

For their kind comments and suggestions, authors thank to Dr. Christian Brannstrom, professor of Geography, Associate Dean for Academic Affairs, and Director of Environmental Programs in Geosciences of Texas A\&M University; and Professor José Drummond, Center for Sustainable Development, Universidade de Brasília,

\section{REFERENCES}

[1] I. Ilich, "The social construction of energy," News Geographies 2: Landscapes of Energy, Havard University Press, pp. 11-23, 2009.

[2] A. Nadaï and D. Horst, "Introduction to landscapes of energies," Landscape Research, vol. 02, no. 35, pp. 143-155, 2010.

[3] A. Smith, A. Stirling, and F. Berkhout, "The governance of sustainable socio-technical transitions," Research Policy, vol. 03, no. 34, pp. 1491-1510, 2005.

[4] F. W. Geels and J. Schott, "Typology of sociotechnical transition pathways," Research Policy, vol. 03, no. 36, pp. 399-417, 2007.

[5] B. Cashore, "Legitimacy and privatization of environmental governance: How non-state market-driven governance systems gain rule-making authority," Governance, vol. 15, no. 04, pp. 503-529, 2002.

[6] E. Swyngendouw, "Authoritarian governance, power and politics of rescaling environment and planning," Society and Space, vol. 18, pp. 63-76, 2000.

[7] M. Grindle, "Good enough governance: poverty reduction and reform in development countries," International Journal of Policy, Administration and Institutions, vol. 17, no. 04, pp. 525- 548, 2004.

[8] T. W. Luke, "On Environmentality: Geo-power and eco-knowledge in the discourses of contemporary environmentalism," Cultural Critique, no. 31, pp. 57-58, 1995.

[9] T. W. Luke, "Environmentality as green governmentality" Discourses of the Environment, Blackwell, Oxford, 1999, pp. 121-151.

[10] A. Agrawal, "Environmentality: Community, intimate government, and the making of environmental subjects in Kumaon, India," Current Anthropology, vol. 46, no. 02, pp. 161-190, 2005.

[11] J. H. Haggerty, "I'm not greenie but": Environmentality, eco-populism and governance in New Zealand experiences from the Southland white bait fishery," Journal of Rural Studies, vol. 02, no. 23, pp. 222-237, 2007.

[12] E. E. Shoreman and N. Haenn, "Regulation, conservation and collaboration: Ecological anthropology in the Mississippi Delta," Human Ecology: An Interdisciplinary Journal, vol. 01, no. 37, pp. 95-107, 2009.

[13] W. Jepson, C. Brannstrom, and N. Persons, "We don't take the Pledge: Environmentality and environmental skepticism at the epicenter of US windy energy development," Geoforum, no. 43, pp. 851-863, 2012.

[14] Renewables Global Status Report, REN21. (2015). [Online]. Available: http://www.ren21.net/wp-content/uploads/2015/07/gsr2015_keyfindin gs_lowres.pdf

[15] National Agency of Petroleum, natural gas and biofuels (ANP), "Brazilian statistic of oil, natural gas and biofuels," 2011, Rio de Janeiro, Brazil.

[16] A. Lima. "Eco-governamentalidade e governança de recursos energéticos: Entre a prática e o discurso na ação coletiva dos Polos Gaúchos de Biodiesel e dos folhelhos texanos de Eagle Ford Shale," Ph.D. dissertation, Programa de Pós-Graduação em Desenvolvimento 
Sustentável, Centro de Desenvolvimento Sustentável, University of Brasília, Brazil, 2016.

[17] T. Tunstall. "Recent economic and community impact of unconventional oil and gas exploration and production on South Texas Counties in the Eagle Ford Shale area," The Journal of Regional Analysis \& Policy, vol. 45, no. 01, pp. 82-92, 2015.

[18] Brazilian Biodiesel and Biokerosene Association (Ubrabio), "Biodiesel: Sustainable fuel that take cares of the future," Ubrabio Informative, $6^{\text {th }}$ edition, pp. 01-06, 2012.

[19] M. Stralow, "The Buzbee law firm: Championing the oilfield worker," Eagle Ford Shale Magazine, vol. 2, no. 4, pp. 12-13, 2014.

[20] C. Brannstrom, "Sustainability for non-sustainable use of natural resources in western Bahia and the Eagle Ford Shale of Texas," Mercator, vol. 14, no. 01, pp. 89-94, 2015.

[21] Brazilian Biodiesel and Biokerosene Association (Ubrabio), "Biodiesel: Go ahead: Sustainable road," Biodiesel in Focus, vol. 01, no. 03, May 2011.

[22] A. Dupper, "Going green: The virtues of fracking," Eagle Ford Shale Magazine, vol. 02, no. 03, pp. 62-63, 2014.

[23] S. Higgins, "Will Obama go down in history as the "fracking president"?" Washington Examiner, June 6, 2013.

[24] Apache Corporation, "Energizing a sustainable future," 2013 Summary Sustainability Report.

[25] R. C. Prado and A. C. Andrade, "Petrobras biodiesel: The planted energy," presented at the Rural Show Coopavel Biodiesel, Cascavel, Brazil, February 05-09, 2007.

[26] American Petroleum Institute, "America's energy revolution: How fracking has transformed the U.S. into an energy superpower," API Informative, 2014

[27] M. Stralow, "Oil self suficiency," Eagle Ford Shale Magazine, vol. 1, no. 4 , pp. 11-12, 2013

[28] T. Tunstall, "The multiplier effect in Texas," Eagle Ford Shale Magazine, vol. 02, no. 03, pp. 50-51, 2014

[29] C. R. Freitas. "Fandango gaúcho," BiodieselBr, vol. 06, no. 37, pp. 24-29, 2013.

[30] V. Boreki, "Distribuindo riqueza," BiodieselBr, vol. 06, no. 36, pp. $32-35,2013$.

[31] B. Mealer, "Y'all smell that? That's the smell of money: Chasing the boom in South Texas," Texas Monthly, November 2013.

[32] D. C. Morton, R. S. DeFries, Y. E. Shimabukuro, L. O. Anderson, E. Aral, F. D. B. Espirito-Santo, R. Freitas, and J. Morisette, "Cropland expansion changes deforestation dynamics in the southern Brazilian Amazon," PNAS, vol. 103, no. 39, pp. 14637-14641, 2006.

[33] D. Benedetti, E. Nunes, M. Sarmento, C. Porto, C. E. I. Santos, J. F. Dias, and J. Silva. "Genetic damage in soybean workers exposed to pesticides: Evaluation with the comet and bucal micronucleus cytome assays," Mutation Research/Genetic Toxicology and Environmental Mutagenesis, vol. 752, pp. 28- 33, 2013.

[34] J. L. Adgate, B. D. Goldstein, and L. M. Mckenzie, "Potential public health hazards, exposures and health effects from unconventional natural gas development," Environmental Science \& Technology, vol 48, pp. 8307-8320, 2014
[35] M. S. Mauter, P. J. J. Alvarez, A. Burton, D. C. Cafaro, W. Chen, K. B. Gregory, G. Jiang, Q. Li, J. Pittock, D. Reible, and J. L. Schnoor, "Regional variation in water-related impacts of shale gas development and implications for emerging international plays," Environmental Science \& Technology, vol. 48, pp. 8298-8306, 2014.

[36] C. P. T. Prates, E. C. Pierobon, and R. C. Costa. "Formação do mercado de biodiesel no Brasil," BNDES Setorial, no. 25, pp. 39-64, 2007.

[37] V. C. Silveira, J. A. González, and E. L. Fonseca, "Land use changes after the period commodities rising price in the Rio Grande do Sul State, Brazil," Ciência Rural, vol. 47, no. 04, pp. 02-07, 2017.

[38] P. Erdos, "Have oil and gas prices got separated?" Energy Policy, vol. 49, pp. 707- 718, 2012.

[39] K. W. Costello, "Exploiting the abundance of U.S. shale gas: Overcoming obstacles to fuel switching and expanding the gas distribution system," Energy Law Journal, vol. 34, pp. 541-587, 2013

[40] J. B. Jacquet." "Review of risks to communities from shale energy development," Environmental Science \& Technology, vol. 48, pp. 8321- 8333, 2014.

[41] M.. J. Small, P. C. Stern, E. Bomberg, S. M. Christopherson, B. D. Goldstein, A, L. Israel, R. B. Jackson, A. Krupnick, M. S. Mauter, J. Nash, D. W. North, S. M. Olmstead, A. Pralash, B. Rabe, N Richardson, S. Tierney, T. Webler, and G. W. Parodi. "Risk and risk governance in unconventional shale gas," Environmental Science \& Technology, vol. 48, pp. 8289- 8297, 2014.

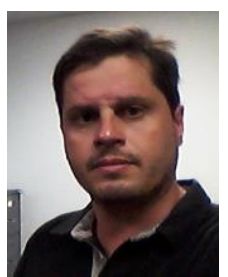

Arnoldo Lima was born in Santa Maria, Brazil on August 28, 1973. He graduate in geography (2005). He received his Ph.D. on policy and sustainability management in 2016 from Center for Sustainable Development (CDS) at University of Brasília (UnB).

His main research field is resource governance an environmentality.

He has being studying socio-environmental impacts linked to energy and bioenergy production since 2009. In 2014 he was invited to the Human-Environment Research Group at Texas A\&M University/Dpt. Of Geography when he worked as a researcher in Eagle Ford Shale energy landscape. Currently he is Ad-Hoc Advisor for Federal District Research Foundation (FAPDF) and Postdoctoral Associated Researcher at $\mathrm{CDS} / \mathrm{UnB}$.

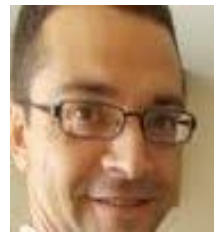

Fabiano Toni was born in São Paulo, Brazil. He graduated in agronomic engineering at University of São Paulo (1989) and the master in economic sciences at State University of Campinas (1994). He received his $\mathrm{PhD}$ in political science from University of Florida in 1999 .

He is currently professor at the University of Brasília, where he coordinates the postgraduate program in sustainable development. Fabiano has experience in political science and mainly works on the following topics: decentralization, Amazon, environmental policy, forest policy and social movements. 